\title{
High Brain Tissue Oxygen Tension During Ventilation With 100\% Oxygen After Fetal Asphyxia in Newborn Sheep
}

\author{
VALERIA PEREZ-DE-SA, DORIS CUNHA-GONCALVES, ANDERS NORDH, STEFAN HANSSON, ANDERS LARSSON, \\ DAVID LEY, VINETA FELLMAN, AND OLOF WERNER
}

\begin{abstract}
Departments of Pediatric Anesthesia and Intensive Care [V.P.-S., A.N., O.W.], Pediatrics [D.L., V.F.], Thoracic Anesthesia and Intensive Care [D.C.-G.], and Obstetrics [S.H.], University Hospital of Lund, Lund, Sweden, SE-22185; Clinical Institute [A.L.], Aarhus University, Aalborg, Denmark, DK-9100; Department of Pediatrics [V.F.], University of Helsinki, 00029 Helsinki, Finland
\end{abstract}

\begin{abstract}
The optimal inhaled oxygen fraction for newborn resuscitation is still not settled. We hypothesized that short-lasting oxygen ventilation after intrauterine asphyxia would not cause arterial or cerebral hyperoxia, and therefore be innocuous. The umbilical cord of fetal sheep was clamped and 10 min later, after delivery, ventilation with air $(n=7)$ or with $100 \%$ oxygen for $3(n=6)$ or 30 $\min (n=5)$, followed by air, was started. Among the 11 lambs given $100 \%$ oxygen, oxygen tension $\left(\mathrm{P}_{\mathrm{O} 2}\right)$ was $10.7(1.8-56) \mathrm{kPa}$ [median (range)] in arterial samples taken after $2.5 \mathrm{~min}$ of ventilation. In those ventilated with $100 \%$ oxygen for $30 \mathrm{~min}$, brain tissue $\mathrm{P}_{\mathrm{O} 2}\left(\mathrm{Pbt}_{\mathrm{O} 2}\right)$ increased from less than $0.1 \mathrm{kPa}$ in each lamb to individual maxima of $56(30-61) \mathrm{kPa}$, whereas in those given oxygen for just $3 \mathrm{~min}$, $\mathrm{Pbt}_{\mathrm{O} 2}$ peaked at $4.2(2.9-46) \mathrm{kPa}$. The maximal $\mathrm{Pbt}_{\mathrm{O} 2}$ in airventilated lambs was $2.9(0.8-5.4) \mathrm{kPa}$. Heart rate and blood pressure increased equally fast in the three groups. Thus, prolonged ventilation with $100 \%$ oxygen caused an increase in $\mathrm{Pbt}_{\mathrm{O} 2}$ of a magnitude previously only reported under hyperbaric conditions. Reducing the time of $100 \%$ oxygen ventilation to $3 \mathrm{~min}$ did not consistently avert systemic hyperoxia. (Pediatr Res 65: 57-61, 2009)
\end{abstract}

$\mathrm{C}$ urrent guidelines from the International Liaison Committee on Resuscitation breathe considerable uncertainty as to how much supplementary oxygen should be given during resuscitation of newborn asphyxiated infants (1). Previous recommendations were to be generous with oxygen, but recent guidelines from a number of countries, e.g. Australia, Canada, Finland, the Netherlands, Sweden, and the United Kingdom recommend initial ventilation with air, because of the results from several experimental (2-5) and clinical (6-13) studies indicating that resuscitation with $100 \%$ oxygen is harmful. In the clinical studies, the time of exposure to $100 \%$ oxygen was typically 5-7 $\min (8,13)$, whereas only one animal study (5) has investigated an exposure time to oxygen less than $15 \mathrm{~min}$.

We speculated that very short times of exposure might not allow systemic hyperoxia to develop and so be harmless to the newborn infant, except for a possible negative effect on the lungs. In fact, the pulse oximetric saturation at $3 \mathrm{~min}$ after birth is usually below $80 \%(14,15)$ in the normal air-breathing

Received April 29, 2008; accepted August 6, 2008.

Correspondence: Valeria Perez-de-Sa, M.D., Ph.D., D.E.A.A., Department of Pediatric Anesthesia and Intensive Care, Children's Hospital, University Hospital of Lund, Lund, Sweden, SE-221 85; e-mail: valeria.perezdesa@gmail.com

Supported by The Laerdal Foundation, The Swedish Medical Research Council (grant nos 14940, 4732), University Hospital of Lund and Lund's Medical Faculty grants, the Segerfalk Foundation, and the Craaford Foundation. infant, suggesting the presence of cardiac or pulmonary rightto-left shunts. One might expect that such shunts would delay the appearance of arterial hyperoxemia in the infant breathing pure oxygen. However, this has been studied neither in normal nor in asphyxiated subjects.

We used a sheep model of term intrauterine asphyxia with postnatal resuscitation, and hypothesized that hyperoxia of arterial blood and of brain tissue could be prevented by limiting the period of ventilation with $100 \%$ oxygen to $3 \mathrm{~min}$. We also investigated whether the speed of circulatory recovery, as reflected by the heart rate (HR) and mean arterial blood pressure (MAP) responses, and the speed of recovery of brain oxygenation, as reflected by regional cerebral oxygen saturation $\left(\mathrm{CrS}_{\mathrm{O} 2}\right)$, differed between oxygen- and air-resuscitation.

Work on the same animal model has shown that the mRNA expression of some proinflammatory cytokines in the brain is increased in asphyxiated lambs $90 \mathrm{~min}$ after exposure to 30 min of $100 \%$ oxygen breathing (16), and a secondary aim was to see whether already $3 \mathrm{~min}$ with pure oxygen could generate the same inflammatory response.

\section{METHODS}

The study was approved by the Animal Ethics Research Committee of Lund University. The animals were cared for and handled in accordance with European Guidelines for Use of Experimental Animals.

Animal preparation and cerebral oxygenation measurements. Datemated ewes were anesthetized and underwent cesarean section at 140-141 gestational days, when pulmonary surfactant function in the lamb is usually normal (17). Term is $145-150 \mathrm{~d}$. The fetus received catheters in an axillary artery and a jugular vein, and was tracheotomized as described previously (16).

The scalp was shaved and an incision made to expose the right parietal bone. A hole of 3-mm diameter was drilled down to the dura mater, and a hollow bolt screwed into the hole. By using an introducer passed through the lumen of the bolt, a flexible microcatheter probe containing a polarographic cell (LICOX; GMS, Mielkendorf, Germany) was placed with its tip in the subcortex so that brain tissue $\mathrm{Po}_{2}\left(\mathrm{Pbt}_{\mathrm{O} 2}\right)$ could be continuously measured. Alongside the $\mathrm{Pbt}_{\mathrm{O} 2}$ probe, a thermocouple probe was placed through the same introducer, and both were connected to a LICOX CMP monitor for automatic temperature-corrected $\mathrm{Pbt}_{\mathrm{O} 2}$ readings. Every $20 \mathrm{~s}$, the $\mathrm{Pbt}_{\mathrm{O} 2}$ and temperature signals were collected and stored in a personal computer using the LICOX for PC Software. The $\mathrm{Pbt}_{\mathrm{O} 2}$ recording was later processed to find the individual's maximum (peak) value.

Abbreviations: BE, arterial base excess; $\mathbf{B p m}$, beats per minute; $\mathbf{C r S}_{\mathbf{O 2}}$, regional cerebral oxygen saturation; $\mathbf{F i}_{\mathbf{O} 2}$, inspired fraction of oxygen; $\mathbf{H b}$, hemoglobin; HR, heart rate; MAP, mean arterial pressure; $\mathbf{P b t}_{\mathbf{O} 2}$, brain tissue partial pressure of oxygen 
Measurement of $\mathrm{CrS}_{\mathrm{O} 2}$ by dual wavelength near-infrared spectroscopy, was performed with equipment for clinical use (INVOS ${ }^{\circledR} 5100 \mathrm{C}$ Cerebral/ Somatic Oxymeter, Somanetics Corporation, Troy, MI), using a disposable self-adherent pediatric probe (Pediatric SomaSensor probe, $<40 \mathrm{~kg}$, model SPFB-USA, Somanetics Corporation) that was attached to the shaved scalp and secured in place by a fabric net.

Induction of asphyxia and resuscitation. After clamping and cutting the umbilical cord, the lamb was removed from the womb, weighed, sedated, and placed in an open, heated incubator. A catheter was positioned in the abdominal aorta via the umbilical cord and used for recording MAP and HR on a Datex-Ohmeda AS/3 Compact Anesthesia Monitor (GE Health Care, Helsinki, Finland). Pressure-regulated volume control ventilation with a Servo 300 ventilator (Siemens-Elema, Solna, Sweden) was initiated exactly $10 \mathrm{~min}$ after cord occlusion. Tidal volume was $10 \mathrm{~mL} / \mathrm{kg}$, respiratory rate 40/min, I:E ratio 1:1, and end-expiratory pressure $4 \mathrm{~cm} \mathrm{H}_{2} \mathrm{O}$. The lambs were randomized to receive an inhaled oxygen fraction $\left(\mathrm{Fi}_{\mathrm{O}_{2}}\right)$ that was either $21 \%$ $(n=7)$ throughout or $100 \%$ during the first $3(n=6)$ or $30 \min (n=6)$ of ventilation. The ventilation with pure oxygen was followed by ventilation with air. One lamb of the 30-min oxygen group was subsequently excluded because of low blood hemoglobin $(\mathrm{Hb})$ concentration; see Results. An observer, blinded to the $\mathrm{Fi}_{\mathrm{O} 2}$, looked at the arterial pressure curve, to judge whether the circulation showed signs of spontaneous recovery after start of ventilation. If not, $10 \mu \mathrm{g} / \mathrm{kg}$ of adrenaline was injected i.v., and external cardiac massage given for $15 \mathrm{~s}$. After the first half hour, respiratory rate was adjusted to achieve an arterial $\mathrm{PcO}_{2}\left(\mathrm{~Pa}_{\mathrm{CO}}\right)$ around $6 \mathrm{kPa}$.

Arterial sampling. A $0.5 \mathrm{~mL}$ sample for blood-gas and $\mathrm{Hb}$ measurements was obtained from the axillary artery catheter shortly before occluding the umbilical cord (in utero), just before start of ventilation (end of asphyxia), and $0.75,2.5,5,10,15,29.5$, and $60 \mathrm{~min}$ after start of ventilation. The samples were analyzed on an ABL 700 blood-gas analyzer (Radiometer, Copenhagen, Denmark). Its settings were adjusted to ovine blood, according to a factoryinstalled algorithm.

Assessment of circulatory recovery and of recovery of cerebral oxygenation. The time from start of ventilation until $\mathrm{HR}$ had increased to $150 \mathrm{bpm}$ was measured. We also assessed the time from start of ventilation until $\mathrm{CrS}_{\mathrm{O} 2}$ reached $30 \%$, i.e. a value just above the minimum displayed by the equipment, namely $15 \%$. Because a new $\mathrm{CrS}_{\mathrm{O} 2}$ figure was presented every $6 \mathrm{~s}$, and the HR and MAP every $10 \mathrm{~s}$, interpolation was used to calculate the times to the nearest second.

In a separate analysis, individual HR and MAP curves were aligned, so that the respective points in time when HR reached $150 \mathrm{bpm}$ coincided. The respective mean curves representing each group were then calculated.

Experiments in nonasphyxiated controls. Subsequent to the asphyxia series, four nonrandom controls were ventilated with oxygen to assess cerebral oxygenation during hyperoxemia that was not preceded by asphyxia. Using an infant self-expanding resuscitator bag, manual ventilation with air started with the lamb in utero, a few seconds before clamping and cutting the umbilical cord. The lamb was transferred to the open incubator where mechanical ventilation with $100 \%$ oxygen was initiated as soon as an aortic catheter had been placed via the umbilical cord, for pressure monitoring. After
$30 \mathrm{~min}$, the inspired gas was changed to air. Axillary arterial samples for blood-gas and $\mathrm{Hb}$ measurements were taken in utero, and 0.75, 2.5, 5, 10, 15, 29.5 , and $60 \mathrm{~min}$ after switching from air- to oxygen-ventilation. The preparation, ventilator settings, sedation, and measurements were otherwise the same as for the asphyxiated animals.

mRNA expression in the brain of proinflammatory cytokines IL-1 $\beta$, IL-12, and IL-18. After the $60 \mathrm{~min}$ arterial sample, the heart was arrested by an i.v. injection of potassium chloride. In 13 asphyxiated animals and three controls, the brain was immediately removed from the skull and split in the midline. In the left half, tissue sections were taken from the temporo-parietal cortex including sub-cortical white matter and from the thalamus, and immediately frozen on dry ice. The samples were stored at $-80^{\circ} \mathrm{C}$.

Total RNA was extracted from frozen tissue using Trizol ${ }^{\circledR}$ (GIBCO BRL, Invitrogen Corporation, Grand Island, NY) according to the manufacturer's instructions. Gene transcripts were quantified using real-time PCR on ABI PRISM $^{\circledR} 7000$ sequence detection system (Applied Biosystems, Foster City, CA) as described previously (10). The quantitative value of each sample was normalized to the corresponding value of beta-actin and results expressed as relative values.

Statistics. Between-group differences among asphyxiated lambs were assessed by analysis of variance using Sigma Chemical Co.-Stat 3.5 software (Systat Software GmbH, Ekrath, Germany). In case of non-normal distribution, analysis of variance on ranks was used instead. The difference in peak $\mathrm{Pbt}_{\mathrm{O} 2}$ between the group of asphyxiated lambs that was ventilated with oxygen for $30 \mathrm{~min}$ and the nonasphyxiated lambs was assessed with the $t$ test.

\section{RESULTS}

One asphyxiated lamb, randomized to resuscitation with oxygen for $30 \mathrm{~min}$, was excluded because of a low $\mathrm{Hb}: 60 \mathrm{~g} / \mathrm{L}$. Among the remaining 18 asphyxiated animals, the median (range) for $\mathrm{Hb}$ was $136(119-157) \mathrm{g} / \mathrm{L}$, with no difference between the three groups. Hb was $127(95-151) \mathrm{g} / \mathrm{L}$ in the four nonasphyxiated animals.

Asphyxiated lambs. Table 1 shows arterial blood gases and base excess (BE) by group. In utero $\mathrm{pH}$ (not shown in the Table) of all 18 subsequently asphyxiated animals was 7.26 (7.10-7.32). There was no significant difference between groups in respect of any of these measures.

During the cord occlusion, median arterial $\mathrm{P}_{\mathrm{O} 2}\left(\mathrm{~Pa}_{\mathrm{O} 2}\right)$ decreased to $0.74 \mathrm{kPa}$, and a severe combined respiratory and metabolic acidemia developed, with a median $\mathrm{Pa}_{\mathrm{CO} 2}$ of 17 $\mathrm{kPa}$, and $\mathrm{BE}$ of $-13 \mathrm{mM}$. pH decreased to 6.92 (6.81-6.99). $\mathrm{Pbt}_{\mathrm{O} 2}$ became less than $0.1 \mathrm{kPa}$ in all animals, and $\mathrm{CrS}_{\mathrm{O} 2}$ was

Table 1. Arterial blood gases

\begin{tabular}{|c|c|c|c|c|c|c|}
\hline Group & In utero & End of asphyxia & $45 \mathrm{~s}$ & $2.5 \min$ & $29.5 \mathrm{~min}$ & $60 \mathrm{~min}$ \\
\hline \multicolumn{7}{|c|}{ Asphyxia, air $(n=7)$} \\
\hline $\mathrm{Pa}_{\mathrm{O} 2}(\mathrm{kPa})$ & $3.0(1.4-4.0)$ & $0.6(0.5-1.6)$ & $2(0.6-3.3)$ & $3.0(1.1-11)$ & $5.2(2.7-12)$ & $6.0(1.9-11)$ \\
\hline $\mathrm{Pa}_{\mathrm{CO} 2}(\mathrm{kPa})$ & $9.0(7.8-10)$ & $17(16-19)$ & $17(15-17)$ & $13(8.1-16)$ & $5.5(4.9-11)$ & $5.1(3.8-6.5)$ \\
\hline $\mathrm{BE}(\mathrm{mmol} / \mathrm{L})$ & $0(-9$ to +2$)$ & $-14(-21$ to -8$)$ & $-12(-21$ to -9$)$ & $-11(-20$ to -9$)$ & $-9(-15$ to -1$)$ & $-3(-11-+3)$ \\
\hline \multicolumn{7}{|c|}{ Asphyxia, oxygen $3 \min (n=6)$} \\
\hline $\mathrm{Pa}_{\mathrm{O} 2}(\mathrm{kPa})$ & $1.8(1.6-3.5)$ & $0.9(0.5-1.0)$ & $3.1(0.5-4.3)$ & $26(5.4-56)$ & $5.2(3.1-10)$ & $4.5(2.6-8.3)$ \\
\hline $\mathrm{Pa}_{\mathrm{CO} 2}(\mathrm{kPa})$ & $8.9(7.8-9.6)$ & $17(14-19)$ & $15(8.0-17)$ & $13(7.0-15)$ & $6.2(5.2-7.5)$ & $6.3(5.3-7.5)$ \\
\hline $\mathrm{BE}(\mathrm{mmol} / \mathrm{L})$ & $-1(-2$ to +2$)$ & $-12(-15$ to -8$)$ & $-13(-15$ to -9$)$ & $-13(-14$ to -8$)$ & $-5(-8$ to -3$)$ & $-1(-3$ to +4$)$ \\
\hline \multicolumn{7}{|c|}{ Asphyxia, oxygen $30 \min (n=5)$} \\
\hline $\mathrm{Pa}_{\mathrm{O} 2}(\mathrm{kPa})$ & $2.4(1.5-3.4)$ & $0.9(0.6-1.3)$ & $2.1(0.9-3.2)$ & $5.5(1.8-51)$ & $21(6.1-65)$ & $3.8(3.5-5.5)$ \\
\hline $\mathrm{Pa}_{\mathrm{CO} 2}(\mathrm{kPa})$ & $8.0(7.2-11)$ & $17(15-19)$ & $17(16-18)$ & $15(7.8-16)$ & $8.2(5.7-12)$ & $6.2(5.2-8.4)$ \\
\hline $\mathrm{BE}(\mathrm{mmol} / \mathrm{L})$ & $+1(-2$ to +2$)$ & $-13(-14$ to -10$)$ & $-12(-15--10)$ & $-13(-15$ to -11$)$ & $-7(-8$ to -6$)$ & $-3(-5$ to -2$)$ \\
\hline \multicolumn{7}{|c|}{ No asphyxia, oxygen $30 \min (n=4)$} \\
\hline $\mathrm{Pa}_{\mathrm{O} 2}(\mathrm{kPa})$ & $1.8(1.4-2.6)$ & - & $46(5.6-49)$ & $47(33-58)$ & $58(7.4-63)$ & $7.0(4.0-7.4)$ \\
\hline $\mathrm{Pa}_{\mathrm{CO} 2}(\mathrm{kPa})$ & $8.4(6.0-9.1)$ & - & $8.0(6.7-10)$ & $9.7(7.6-11)$ & $4.8(4.4-7.5)$ & $4.6(4.2-5.4)$ \\
\hline $\mathrm{BE}(\mathrm{mmol} / \mathrm{L})$ & $-5(-8$ to -3$)$ & - & $-4(-7$ to -2$)$ & $-6(-12$ to -2$)$ & $0(-8$ to +4$)$ & $2(-1$ to +3$)$ \\
\hline
\end{tabular}

$\mathrm{Pa}_{\mathrm{O} 2}, \mathrm{~Pa}_{\mathrm{CO} 2}$, and base excess (BE) before asphyxia (in utero), just before start of ventilation (end of asphyxia), and at various times after start of ventilation in the three groups of asphyxiated lambs. For nonasphyxiated control animals, times are after switching from air- to oxygen-ventilation. Values are median (range). 
Table 2. Times from start of ventilation until heart rate $(H R)$ reached $150 \mathrm{bpm}$, and until cerebral regional oxygen saturation $\left(\mathrm{Cr} \mathrm{S}_{\mathrm{O} 2}\right)$ reached $30 \%$ in asphyxiated lambs

\begin{tabular}{|c|c|c|c|c|}
\hline & \multicolumn{3}{|c|}{ Asphyxia } & \multirow{2}{*}{$\begin{array}{c}\text { No asphyxia } \\
\text { Oxygen for } 30 \mathrm{~min} \\
(\mathrm{n}=4)\end{array}$} \\
\hline & $\begin{array}{c}\text { Air } \\
(\mathrm{n}=7)\end{array}$ & $\begin{array}{l}\text { Oxygen for } 3 \mathrm{~min} \\
\qquad(\mathrm{n}=6)\end{array}$ & $\begin{array}{l}\text { Oxygen for } 30 \mathrm{~min} \\
(\mathrm{n}=5)\end{array}$ & \\
\hline Time (s) until HR $\geq 150 \mathrm{bpm}$ & $68(6-150)$ & $107(5-182)$ & $58(23-368)$ & - \\
\hline Time (s) until $\mathrm{CrSO}_{2} \geq 30 \%$ & $112(35-590)$ & $54(35-109)$ & $26(23-206)$ & - \\
\hline Peak $\mathrm{Pbt}_{\mathrm{O} 2}(\mathrm{kPa})$ & $2.9(0.8-5.4)$ & $4.2(2.9-46)$ & $56(30-61)^{*}$ & $15(6.5-22)$ \\
\hline
\end{tabular}

Individual maxima for brain tissue oxygen tensions (peak $\mathrm{Pbt}_{\mathrm{O} 2}$ ).

Values are median (range).

* Significant difference $v s$ no asphyxia $(p=0.002)$.
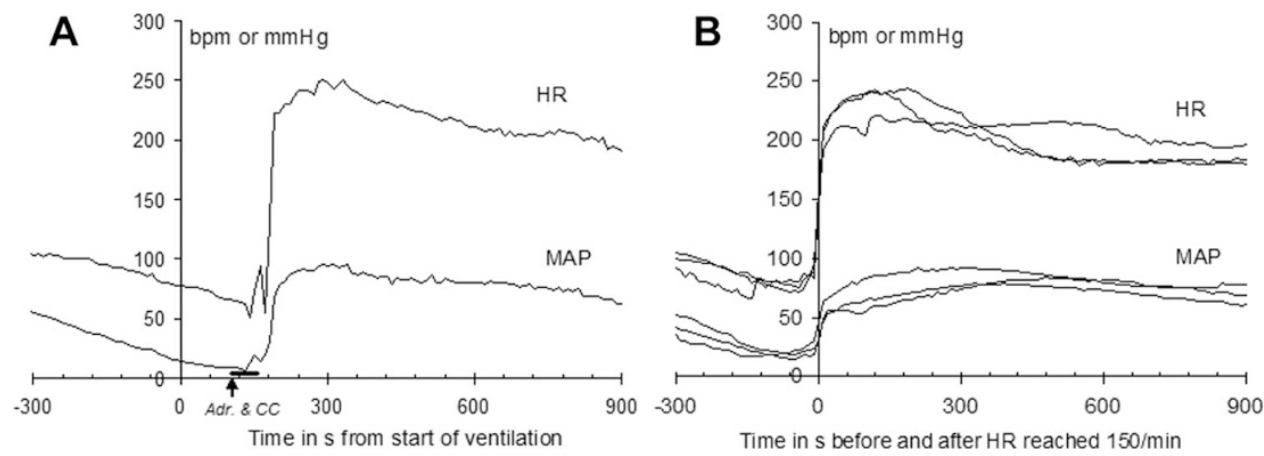

Figure 1. Heart rate and arterial pressure response to resuscitation. (A) HR and MAP in a lamb that was resuscitated with oxygen for 3 min, and then with air ventilation. The arrow and horizontal bar indicate injection of adrenaline and subsequent cardiac compressions. All lambs had a similar abrupt increase in HR from less than 100/min to more than 200/min, concomitant with a likewise abrupt increase of arterial pressure, signaling that the resuscitation was successful. The time when this occurred varied between individuals, but not between groups (Table 2). (B) Mean curves for HR and MAP in the three groups of asphyxiated lambs. They were obtained by aligning curves from individual lambs, so that the times when HR reached 150/min coincided, and then computing the mean curve. This method was chosen in order that the mean curves should reflect the above-mentioned abrupt increase in HR and MAP.

displayed as the minimum value for the equipment, i.e. $15 \%$, in all animals. MAP decreased to a nadir of 14 (7-20) $\mathrm{mm} \mathrm{Hg}$ in 17 animals and to $32 \mathrm{~mm} \mathrm{Hg}$ in one. HR decreased to 64 (30-96) bpm. There was no difference between the groups in any of these measures.

The circulation recovered spontaneously when ventilation was started, except in one lamb in the air-only group and in two in each of the two oxygen groups. These five lambs were successfully resuscitated with adrenaline and external cardiac massage. Time to reach a HR of $150 \mathrm{bpm}$ was the same with oxygen-ventilation as with air (Table 2) and curves representing mean HR and MAP were similar in the three groups (Fig. 1). Median time to reach a $\mathrm{CrS}_{\mathrm{O} 2}$ of $30 \%$ was 2 min in those air-ventilated and $1 / 2-1 \mathrm{~min}$ in the two groups given $100 \%$ oxygen (Table 2). The difference between groups was not significant $(p=0.084)$.

After $45 \mathrm{~s}$ of ventilation, $\mathrm{Pa}_{\mathrm{O} 2}$ had increased slightly in most animals, but there was no arterial hyperoxemia (Table 1). Such was seen at $21 / 2$ min when $\mathrm{Pa}_{\mathrm{O} 2}$ was over $50 \mathrm{kPa}$ in three lambs ventilated with oxygen. In the samples taken at 5, 10, and $15 \mathrm{~min}$, the median $\mathrm{Pa}_{\mathrm{O} 2}$ was over $55 \mathrm{kPa}$ in lambs allotted to prolonged oxygen breathing (Fig. 2C), and $\mathrm{Pbt}_{\mathrm{O} 2}$ generally increased to peak values over $50 \mathrm{kPa}$ in these (Fig. 2C, Table 2). Among lambs ventilated with pure oxygen for just $3 \mathrm{~min}, \mathrm{Pbt}_{\mathrm{O} 2}$ peaked at $46 \mathrm{kPa}$ in one, and was $2.9-5.4$ $\mathrm{kPa}$ in the other five (Fig. 2B). When oxygen-ventilation was discontinued, $\mathrm{Pbt}_{\mathrm{O} 2}$ decreased to essentially the same levels as in the air-only group (Fig. 2).
Nonasphyxiated controls. At the intrauterine (baseline) stage, arterial oxygenation and $\mathrm{Pa}_{\mathrm{CO} 2}$ were similar to those in the other groups (Table 1), but BE tended to be somewhat more negative. During $30 \mathrm{~min}$ of oxygen breathing, $\mathrm{Pa}_{\mathrm{O} 2}$ levels were approximately the same as in those asphyxiated lambs that were ventilated equally long with oxygen (Fig. 2D), whereas peak $\mathrm{Pbt}_{\mathrm{O} 2}$ was significantly less (Table 2).

Cytokines in cerebral tissue. IL-1 $\beta$, IL-12, and IL-18 (Table 3 ) did not vary significantly between groups.

\section{DISCUSSION}

The main finding of the present study is the extremely high $\mathrm{Pbt}_{\mathrm{O} 2}$ of asphyxiated lambs, exposed to prolonged ventilation with $100 \%$ oxygen (Fig. 2C). The peak value was 56 (30-61) $\mathrm{kPa}$, and such a high $\mathrm{Pbt}_{\mathrm{O} 2}$ has been previously seen only under hyperbaric conditions (18). The finding is probably due to a combination of factors, namely high $\mathrm{Fi}_{\mathrm{O} 2}$, postischemic hyperemia accentuated by metabolic and respiratory arterial acidemia, and reduced metabolism (19) in the postasphyctic brain. Surprisingly, Lyng et al. (20) found a much smaller peak $\mathrm{Pbt}_{\mathrm{O} 2}$ in 1-2-d-old piglets that were asphyxiated by breathing an hypoxic mixture and then resuscitated with 30 min of oxygen-ventilation. In these, $\mathrm{Pbt}_{\mathrm{O} 2}$ only increased to a maximum of approximately $5 \mathrm{kPa}$. The discrepancy could be the result of differences in equipment and species, different $\mathrm{P}_{\mathrm{O} 2}$ electrode placement in the brain, a $\mathrm{Pa}_{\mathrm{CO} 2}$ following asphyxia which was probably less in their study, and the fact 

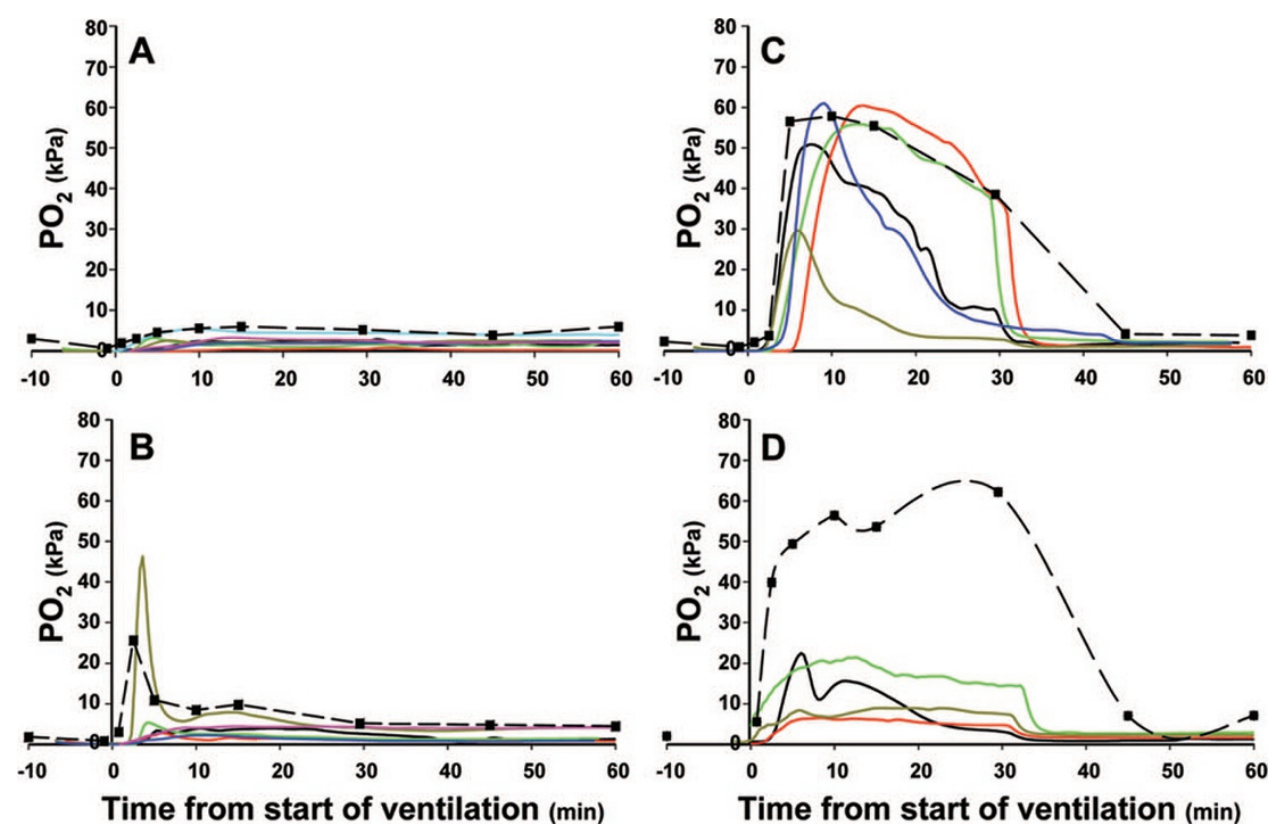

Table 3. Cytokine mRNA activity in cerebral tissue
Figure 2. Brain tissue $\mathrm{P}_{\mathrm{O} 2}\left(\mathrm{Pbt}_{\mathrm{O} 2}\right)$ and arterial $\mathrm{P}_{\mathrm{O} 2}\left(\mathrm{~Pa}_{\mathrm{O} 2}\right)$. Individual curves depicting $\mathrm{Pbt}_{\mathrm{O} 2}$ (continuous lines) in lambs that were asphyxiated in utero and resuscitated after birth, with (A) air-ventilation $(n=7)$ or with $100 \%$ oxygen for (B) 3 min $(n=6)$ or $(\mathrm{C}) 30 \min (n=5)$, and then with air. Group medians for $\mathrm{Pa}_{\mathrm{O} 2}$ (口are also shown. The dot at -10 min represents the $\mathrm{Pa}_{\mathrm{O} 2}$ in utero, before occluding the umbilical cord. (D) In a group that was not made asphyctic $(n=4)$, the $\mathrm{Pbt}_{\mathrm{O} 2}$ and $\mathrm{Pa}_{\mathrm{O} 2}$ during 30 min of oxygen ventilation and a subsequent $30 \mathrm{~min}$ of air ventilation are displayed.

Asphyxia

\begin{tabular}{|c|c|c|c|c|}
\hline & \multicolumn{3}{|c|}{ Asphyxia } & \multirow{2}{*}{$\begin{array}{c}\text { No asphyxia } \\
\text { Oxygen for } 30 \min (n=3)\end{array}$} \\
\hline & Air $(n=5)$ & Oxygen for $3 \min (n=4)$ & Oxygen for $30 \min (n=4)$ & \\
\hline \multicolumn{5}{|l|}{$10^{-3} \times \mathrm{IL}-1 \beta / \beta$-actin } \\
\hline Cortex/subcortex & $25(10-40)$ & $21(17-24)$ & $14(10-31)$ & $21(11-26)$ \\
\hline Thalamus & $16(08-29)$ & $15(13-40)$ & $19(15-36)$ & $29(17-32)$ \\
\hline \multicolumn{5}{|l|}{$10^{-3} \times \mathrm{IL}-12 / \beta$-actin } \\
\hline Cortex/subcortex & $10(0-85)$ & $10(4-26)$ & $52(4-81)$ & $7(0-18)$ \\
\hline Thalamus & $17(12-123)$ & $33(16-46)$ & $9(24-116)$ & $39(22-49)$ \\
\hline \multicolumn{5}{|l|}{ IL- $18 / \beta$-actin } \\
\hline Cortex/subcortex & $1.01(0.99-1.68)$ & $1.54(1.21-1.91)$ & $1.28(0.86-1.91)$ & $1.17(0.90-1.21)$ \\
\hline Thalamus & $1.00(0.92-1.31)$ & $1.54(0.73-3.89)$ & $1.45(0.72-2.07)$ & $1.12(0.94-1.17)$ \\
\hline
\end{tabular}

The result was normalized to $\beta$-actin activity. Values are median (range); $n=$ number of analyzed brains.

that they used a postnatal asphyxia model, rather than one involving the transition from intrauterine to postnatal life.

In the present study, we addressed the question whether arterial and cerebral hyperoxia could be avoided by reducing time of exposure to $100 \%$ oxygen. As it turned out, $\mathrm{Pa}_{\mathrm{O} 2}$ was above $50 \mathrm{kPa}$ already at $2.5 \mathrm{~min}$ in three lambs. Thus, the fluid-filled lungs did not protect the newly delivered lambs from hyperoxemia, except in the arterial sample taken $45 \mathrm{~s}$ after start of ventilation. In addition, one lamb in the 3-min oxygen group had an extremely high $\mathrm{Pbt}_{\mathrm{O} 2}$ peak (Fig. 2B). Whether a similar rapid hyperoxygenation could occur in asphyxiated human neonates is not known. Vento et al. (8)

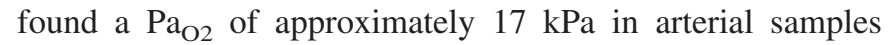
taken approximately 7 min after birth in asphyxiated infants breathing $100 \%$ oxygen. A suggestion that brief exposures could be toxic is given by clinical studies comparing oxygen and air ventilation for resuscitation after asphyxia. In these, an increased mortality (21) and signs of oxidative stress (13) were seen in infants given $100 \%$ oxygen during a mean time of only $7.5 \pm 1.8 \mathrm{~min}$. In addition, an association between neonatal exposure to $100 \%$ oxygen for less than $10 \mathrm{~min}$ and childhood leukemia has been found (10). In another study, neonatal exposure to supplemental oxygen for more than 3 min was associated with an increased risk of subsequent cancer, although a shorter exposure was not (11).

There was no significant increase in mRNA expression of proinflammatory cytokines after $30 \mathrm{~min}$ of $100 \%$ oxygen, in contrast to results in a previous paper (16). In that study, cerebral proinflammatory activity was evaluated at $2 \mathrm{~h}$ after initiation of resuscitation compared with $1 \mathrm{~h}$ in the present study. Sufficient time after hyperoxic exposure may be required for detection of increase in proinflammatory cytokine expression. In addition, the considerably smaller sample size in the present study limits detection of differences between groups.

The INVOS system, that was used to measure $\mathrm{CrS}_{\mathrm{O} 2}$, is adapted to the light absorption characteristics of human $\mathrm{Hb}$, which are slightly different from those of ovine $\mathrm{Hb}$ (22). Nevertheless, the measurement was thought to provide an idea as to how quickly cerebral oxygenation was being restored during resuscitation, and we used the time taken for $\mathrm{CrS}_{\mathrm{O} 2}$ to reach $30 \%$ as an indicator. There was a tendency for this time to be shorter with oxygen ventilation than with air (Table 2), but the groups were not significantly different in this respect. The median time until HR had reached $150 \mathrm{bpm}$ was the same with air ventilation as with oxygen (Table 2), and the MAP 
responses, too, were similar (Fig. 1). This is consistent with previous studies on the same asphyxia model (16) and with studies in asphyxiated 1-3-d-old piglets (23).

In conclusion, the findings in this model of fetal asphyxia followed by neonatal resuscitation indicate that ventilation with air will restore the circulation as fast as when pure oxygen is used, if ventilation is unobstructed and the lungs normal. Prolonged ventilation with $100 \%$ oxygen caused an extreme increase in brain tissue oxygen tension, which emphasizes the need to limit oxygen exposure in the asphyxiated newly born. However, reducing the time of $100 \%$ oxygen ventilation to $3 \mathrm{~min}$ did not consistently avert systemic hyperoxia.

Acknowledgments. We thank Tina Markus for the analysis of cytokine expression in brain tissue, GE Healthcare Technologies for lending a Datex-Ohmeda AS/3 Compact Anesthesia Monitor, and Research Manager, Juha Virtanen, Ph.D., for technical advice.

\section{REFERENCES}

1. The International Liaison Committee on Resuscitation 2006 The International Liaison Committee on Resuscitation (ILCOR) consensus on science with treatment recommendations for pediatric and neonatal patients: pediatric basic and advanced life support. Pediatrics 117:e955-e977

2. Munkeby BH, Børke WB, Bjørnland K, Sikkeland LI, Borge GI, Halvorsen B, Saugstad OD 2004 Resuscitation with 100\% O2 increases cerebral injury in hypoxemic piglets. Pediatr Res 56:783-790

3. Graulich J, Hoffmann U, Maier RF, Ruscher K, Pomper JK, Ko HK, Gabriel S, Obladen M, Heinemann U 2002 Acute neuronal injury after hypoxia is influenced by the reoxygenation mode in juvenile hippocampal slice cultures. Brain Res Dev Brain Res 137:35-42

4. Døhlen G, Carlsen H, Blomhoff R, Thaulow E, Saugstad OD 2005 Reoxygenation of hypoxic mice with $100 \%$ oxygen induces brain nuclear factor-kappa B. Pediatr Res 58:941-945

5. Solas AB, Munkeby BH, Saugstad OD 2004 Comparison of short- and long-duration oxygen treatment after cerebral asphyxia in newborn piglets. Pediatr Res 56:125131
6. Saugstad OD, Rootwelt T, Aalen O 1998 Resuscitation of asphyxiated newborn infants with room air or oxygen: an international controlled trial: the Resair 2 study. Pediatrics 102:e1

7. Ramji S, Rasaily R, Mishra PK, Narang A, Jayam S, Kapoor AN, Kambo I, Mathur A, Saxena BN 2003 Resuscitation of asphyxiated newborns with room air or 100\% oxygen at birth: a multicentric clinical trial. Indian Pediatr 40:510-517

8. Vento M, Asensi M, Sastre J, Lloret A, Garcia-Sala F, Vina J 2003 Oxidative stress in asphyxiated term infants resuscitated with $100 \%$ oxygen. J Pediatr 142:240-246

9. Vento M, Sastre J, Asensi MA, Vina J 2005 Room-air resuscitation causes less damage to heart and kidney than $100 \%$ oxygen. Am J Respir Crit Care Med 172:1393-1398

10. Naumburg E, Bellocco R, Cnattingius S, Jonzon A, Ekbom A 2002 Supplementary oxygen and risk of childhood lymphatic leukaemia. Acta Paediatr 91:1328-1333

11. Spector LG, Klebanoff MA, Feusner JH, Georgieff MK, Ross JA 2005 Childhood cancer following neonatal oxygen supplementation. J Pediatr 147:27-31

12. Rabi Y, Rabi D, Yee W 2007 Room air resuscitation of the depressed newborn: a systematic review and meta-analysis. Resuscitation 72:353-363

13. Vento M, Asensi M, Sastre J, García-Sala F, Pallardó FV, Viña J 2001 Resuscitation with room air instead of $100 \%$ oxygen prevents oxidative stress in moderately asphyxiated term neonates. Pediatrics 107:642-647

14. Kamlin CO, O'Donnell CP, Davis PG, Morley CJ 2006 Oxygen saturation in healthy infants immediately after birth. J Pediatr 148:585-589

15. Rabi Y, Yee W, Chen SY, Singhal N 2006 Oxygen saturation trends immediately after birth. J Pediatr 148:590-594

16. Markus T, Hansson S, Amer-Wåhlin I, Saugstad OD, Hellström-Westas L, Ley D 2007 Cerebral inflammatory response after fetal asphyxia and hyperoxic resuscitation in newborn sheep. Pediatr Res 62:71-77

17. Robertson B 1992 Animal models of neonatal surfactant dysfunction. In: Robertson B, van Golde LM, Batenburg JJ (eds) Pulmonary Surfactant: from Molecular Biology to Clinical Practice. Elsevier Science Publishers B.V., Amsterdam, pp $459-484$

18. van Hulst RA, Haitsma JJ, Klein J, Lachmann B 2003 Oxygen tension under hyperbaric conditions in healthy pig brain. Clin Physiol Funct Imaging 23:143-148

19. Thorngren-Jerneck K, Ley D, Hellström-Westas L, Hernandez-Andrade E, Lingman G, Ohlsson T, Oskarsson G, Pesonen E, Sandell A, Strand SE, Werner O, Marsal K 2001 Reduced postnatal cerebral glucose metabolism measured by PET after asphyxia in near term fetal lambs. J Neurosci Res 66:844-850

20. Lyng K, Braakhuis M, Frøen JF, Stray-Pedersen B, Saugstad OD 2005 Inflammation increases vulnerability to hypoxia in newborn piglets: effect of reoxygenation with 21\% and 100\% O2. Am J Obstet Gynecol 192:1172-1178

21. Saugstad OD 2004 The role of oxygen in neonatal resuscitation. Clin Perinatol 31:431-443

22. Grosenbaugh DA, Alben JO, Muir WW 1997 Absorbance spectra of inter-species hemoglobins in the visible and near infrared regions. J Vet Emerg Crit Care 7:36-42

23. Haase E, Bigam DL, Nakonechny QB, Rayner D, Korbutt G, Cheung PY 2005 Cardiac function, myocardial glutathione, and matrix metalloproteinase-2 levels in hypoxic newborn pigs reoxygenated by $21 \%, 50 \%$, or $100 \%$ oxygen. Shock $23: 383-$ 389 